\title{
Latvijas valsts un ekonomikas ilgtspējas izaicinājumi un riski
}

Identificēt un novērtēt visus iespējamos faktorus, kuri ietekmēs valstu attīstību pēc pandēmijas, brīdī, kad pandēmijai vēl turpina izvērsties, ir ārkārtīgi sarežgíti. Tomēr krīzes seku un valdību reageěšanas spēju salīdzinājums kopš 2020. gada marta lauj konstatēt tendences, kurām būs liela ietekme arì uz valstu attīstību pèc pandēmijas.

Pētījuma mērḳis ir piedāvāt konceptuālu skatījumu uz to, kā apzināt un novērtēt mazu valstu ilgtspējas riskus un noturības faktorus krīzes laikā un pēc krīzes, un sniegt vispārēju vērtējumu par krīzes vadību, kas l̦autu Latvijai îstenot "ilgtspējīgas, taisnīgas un demokrātiskas"l pārmaiņas.

Konceptuālā ietvara centrā ir institūcijas un organizācijas - sociāli mehānismi indivīdu rīcības pielāgošanai situācijās, kad ir svarīga ilgstoša rīcības saskaņotība. ${ }^{2}$ Savā būtībā institūcijas ir pretmets rīcības spontanitātei, un, pateicoties institūcijām, indivīdu rīcība kḷūst prognozējamāka. Krīžu brīžos institūcijas nodrošina mērḳtiecīgāku valsts darbu un pasargā sabiedrību no haosa, savukārt pēc krīzēm bez atbalstošām institūcijām nevar veidoties ilgtspējīga ekonomiskā attīstîba.

1 Ekonomiskās noturības definīcija. Skat.: European Commission. 2020 Strategic Foresight Report: Charting the Course Towards a more Resilient Europe. Communication from the Commission to the European Parliament and the Council COM/ 2020/493 final. 2.

2 Organizācijas ir institūciju kopums, kam ir definēts kopīgs darbības mērḳis un kura ietvaros institūcijas ir savstarpēji sasaistītas ar procedūru palīdzību. Arī valsts pārvaldes iestādes ir organizācijas. Skat.: Polski, M. M., Ostrom, E. (2017). An Institutional Framework for Policy Analysis and Design. In: Elinor Ostrom and the Bloomington School of Political Economy: A Framework for Policy Analysis, Vol. 3 (Lexington Books), 14. 
Valsts kontroles veidotā starptautiskās pieredzes analīze ${ }^{3}$ atklāj, ka tieši no institucionālo mehānismu efektivitātes ir bijušas atkarīgas valstu sekmes Covid-19 izplatības ierobežošanā. Valsts iestāžu spēja ātri reagèt, pastiprināti koordinēt savas darbỉbas un savstarpēji sadarboties bija kritiski svarīga pandēmijas ierobežošanā un cīṇā ar tās sekām apstākḷlos, kad trūka zināšanu par vīrusa dabu un pārsteidza vīrusa izplatības mērogs.

Latvijā Covid-19 pandēmija ir nostrādājusi kā pastāvošo problēmu katalizators. Ir jāpiekrìt Valsts kontroles secinājumam, ka, lai arī valsts iestādēs kritiskas situācijas netika piel̦autas, Latvijas valdība nespēja nodemonstrēt "stingra un izšķiroša" līdera lomu krīzes vadībā. ${ }^{4}$ Arī Latvijas relatīvā ekonomiskā atpalicība no kaimiņvalstīm Igaunijas un Lietuvas, kā arī neveiksmes ar vakcīnu iegādi un savlaicīgu efektīvu vakcinācijas sākšanu liecina par nozīmīgām institūciju darbības efektivitātes problēmām - kḷūdas netiek laikus identificētas, un mācišanās no šìm kḷūdām norit pārāk lēni.

Valsts drošības dienesta secinājums, ka Covid-19 pandēmija ir sniegusi iepriekš nebijušas iespējas nedraudzīgo valstu specdienestiem pētīt Latvijas atbildīgo iestāžu darbu krīzes apstākḷos, tā prognozējot dažādu resoru reageēěanas spēju potenciālas militāras konfrontācijas gadỉjumā ${ }^{5}$, apliecina, ka valsts institucionālās attīstības jautājumi nav triviāli.

Pētỉjuma pirmajā dạ̦ā iepazīstinām ar valsts ilgtspējas novērtējuma konceptuālo ietvaru. Tālāk pievēršamies institūciju efektivitātes analīzei kā valsts ilgtspējas centrālajam elementam, jo bez stipras un viedas pārvaldības krīzes seku pārvarēšana un ekonomiskā izrāviena sekmēšana būs apgrūtināta. Attiecīgi iepazīstinām ar institūciju analīzes shēmu un kā piemēru sniedzam novērtējumu par Latvijas valsts pārvaldes efektivitāti Covid-19 pandēmijas krīzes laikā un ilgtspējīgas attīstības vadības izaicinājumiem.

\section{Valsts ilgtspējas novērtējuma koncepcija}

Latvijas Attīstības plānošanas sistēmas likums ${ }^{6}$ nosaka ilgtspējīgas attīstības principu, kas “tagadējām un nākamajām paaudzēm nodrošina kvalitatīvu vidi un līdzsvarotu ekonomisko attīstību, racionāli izmanto dabas, cilvēku un materiālos

3 Valsts kontrole. (2021). Covid-19 izplatības ierobežošanai nepieciešamo resursu nodrošinājums valsts un pašvaldību institūcijās. Situācijas izpētes ziņojums, 28-31.

4 Valsts kontrole. (2021). Covid-19 izplatības ierobežošanai nepieciešamo resursu nodrošinājums valsts un pašvaldību institūcijās. Situācijas izpētes ziņojums, 5-8.

Valsts drošības dienests. (2021). Publiskais pārskats par Valsts drošības dienesta darbību 2020. gadā. 8.

6 Attīstības plānošanas sistēmas likuma 5. (2) pants. Likumi.lv. Pieejams: https://likumi.lv/ta/id/175748attistibas-planosanas-sistemas-likums. 


\section{1. attēls. Valsts ilgtspējas analīzes novērtējuma koncepcijas shēma}

IEVAINOJAMİBAS

FAKTORI

Ārpolitiskie riski

Ekonomiskā atvērtība

Covid-19, tostarp

- zemas vakcinācijas risks

- stagnācijas risks

- fiskālās ilgtspējas risks

- bankrota un bezdarba riski
NOTURİBAS

FAKTORI

Laba pārvaldība

Institūciju efektivitāte

Biznesa klimats

Uzñēmumu efektivitāte

Produktivitāte

Konkurētspēja

Fiskālā ilgtspēja

Sociālā kohēzija

resursus, saglabā un attīsta dabas un kultūras mantojumu”. Ilgtspējīgas attīstības principa īstenošanā liela loma ir ekonomikas līdzsvarotai attīstībai.

Latvijas valsts ilgtspējas novērtējuma koncepcijas shēma ir parādīta 1. attēlā un ietver mijiedarbību starp ievainojamības un noturības faktoriem. Attiecīgi ekonomiskā ievainojamība ir tautsaimniecības jutīgums pret ārējiem satricinājumiem, kas izriet no ekonomiskās atvērtības, t. i., no faktoriem, kuri atrodas ārpus valdību kontroles, piemēram, augstas eksporta koncentrācijas un importa atkarības. Savukārt ekonomiskā noturība ir tautsaimniecības spēja izturēt vai ātri atgūties no ārējiem ekonomiskiem satricinājumiem, kas ir saistīta ar tirgus dalībnieku un valdību apzināti veidotiem riskus mazinošiem risinājumiem.

Galvenie valsts ievainojamību ietekmējošie faktori ietver starptautiskās vides pārmain,as, valsts ekonomisko atvērtību un Covid-19 pandēmiju. Latvijā ar Covid-19 ir saistīti vairāki riski, tostarp zemas vakcinācijas risks, kas palēnina ekonomikas atvesel̦ošanu, ekonomiskās stagnācijas risks, ja netiks efektīvi izmantoti ekonomikas atvesel̦ošanai paredzētie finanšu resursi, valsts parāda strauja pieauguma risks, kā arī uzņēmumu bankrota un bezdarba riski.

Valsts ilgtspējas novērtējuma koncepcija ir balstīta ANO ekspertu pieejā tautsaimniecības risku novērtēšanai mazu valstu gadījumos. ${ }^{7}$ Par mazām valstīm tiek uzskatītas tādas valstis, kuru tautsaimniecībai ir raksturīga augsta ekonomiskā atvērtība, eksporta koncentrācija un atkarība no stratēgiski nozīmīgu preču 
importa. Atšḳirībā no lielajām valstīm mazās valstis pat pie labākās gribas nespēj panākt tautsaimniecības diversifikāciju, kas tām tiešā veidā ļautu samazināt riskus, kuri izriet no ekonomiskās atvērtības, specializācijas un importa atkarības. Taču, kā apliecina Pasaules ekonomikas foruma Pasaules konkurētspējas ziņojumi, arī mazas valstis spēj būt ekonomiski l̦oti sekmīgas. Piemēram, 2019. gadā starp desmit pasaules konkurētspējīgākajām ekonomikām piecas bija mazās valstis (Singapūra, Honkonga, Nìderlande, Šveice un Dānija).

Mazas valsts ilgtspējas veicinošie faktori ietver labvēlīgu biznesa vidi un uzņēmumu noturību krīzes apstākḷos, kas lielā mērā korelē ar uzṇēmumu darbības efektivitāti. Savukārt izaugsmes potenciāls ir atkarīgs no tautsaimniecības konkurētspējas un produktivitātes. Ekonomisko noturību pret ārējiem ekonomiskiem satricinājumiem var palielināt, apzināti attīstot ekonomiskās institūcijas, kuras spēj absorbēt šo satricinājumu radītās sekas uz tautsaimniecību. Respektīvi, mazo valstu gadījumā ekonomiskā ievainojamība ir dabiska un vienmēr klātesoša, savukārt ekonomiskā noturība - valdības organizēts pasākumu komplekss, ar ko ievainojamību mazināt. Efektīvas un elastīgas institūcijas sekmē mazu valstu noturību pret krīzēm un ḷauj tām sekmīgi konkurēt ar lielajām valstīm.

Piemēram, ir paredzams, ka no tā, vai pēc pandēmijas valstu attīstībā lielāku lomu spēlēs apgādes pašpietiekamība, kas būs lielo valstu priekšrocība, vai institucionālais elastīgums, kas ir mazo valstu priekšrocība, būs atkarīgs, kuras valstis atgūsies ātrāk. Vakcīnu ražošanā vairāk iespēju ir lielajām valstīm, taču vakcinācijas tempu ziṇā arī mazās valstis spēj uzrādìt ḷoti labus rezultātus: Izraēla, Apvienotie Arābu Emirāti un Serbija ir starp līderiem. ${ }^{8}$

ANO pieejā kā galvenie noturību veicinošas rīcības virzieni ir definēti laba valsts pārvaldība (likuma varas un ìpašumtiesību institūtu sekmīga darbība), makroekonomiskā stabilitāte (ierobežots budžeta deficìts un valsts parāds, zems bezdarbs, kontrolējama inflācija), tirgus efektivitāte (netraucēta cenu konkurence un brīva patērētāju izvēle) un sociālā kohèzija (ienākumu vienlīdzība, veselības un izglìtibas kvalitāte un pieejamība, zems nabadzības lìmenis).

Latvijai kā ES dalībvalstij nevar būt problēmu ar tirgus efektivitātes nodrošināšanu, un šis virziens tika izslēgts no Latvijas noturības analīzes. Attiecībā uz makroekonomisko stabilitāti - kaut gan kopš 2008. gada finanšu krīzes Latvija ir demonstrējusi atbildīgu makroekonomisko politiku, Covid-19 krīzes apstākļos veidojas pārmērīga valsts parāda risks, ir iespējama arī pārkāršana atsevišķās nozarēs, kuras tika pie nesamērīga valsts atbalsta (piemēram, būvniecības nozare), un attiecīgs inflācijas pieaugums, kā arī bezdarba palielināšanās. Sociālās

8 Dati iegūti no Our World Data. Statistics and Research: Coronavirus (COVID-19) Vaccinations. Pieejams: https://ourworldindata.org/covid-vaccinations [skatits 27.03.2021.] 
kohēzijas ziṇā Latvijā atpalika no ES vidēja līmeṇa arī pirms pandēmijas krīzes, un esošā krīze tikai palielināja iedzīvotāju ienākumu nevienlīdzību un nabadzības riskus. No institucionālā viedokḷa, kas ir šā raksta skatupunkts, svarīgi izpētīt labas valsts pārvaldības un institūciju efektivitātes stiprināšanas iespējas un šķēršlus.

Ievainojamības un noturības faktoru mijiedarbības analīzes nolūkā monogrāfijas autori lietoja gan subjektīvus, gan objektīvus, empīriski pamatotus vērtējumus. Šajā pētījumā Latvijas valsts pārvaldes efektivitāte tika novērtēta netieši, caur sabiedrỉbas uztveri.

\section{Institūciju analīzes ietvars}

Valsts sekmīga attīstība nav iedomājama bez labi funkcionējošām institūcijām. ${ }^{9}$ Institūcijas ir sociāls rīks/mehānisms indivīdu rīcības pielāgošanai situācijās, kad ir svarīgi pastāvīgi saskaņot rīcību starp diviem vai vairākiem indivīdiem vai indivīdu grupām. ${ }^{10}$ Bez atbalstošām institūcijām nevar veidoties ilgtspējīga ekonomiskā attīstība, bet krīzes brīžos institūcijas nodrošina mērḳtiecīgāku valsts darbu un nepiel̦auj haosu. Vienlaikus - institūcijas var arī attīstību kavēt. Tà kā institūcijas ir pakḷautas lielākai inercei, tad ekonomiskie un institucionālie procesi neattīstās vienādos tempos. Piemēram, institūcijas var neatbilst iekḷaujošas ekonomikas vajadzībām, nenodrošinot attīstības ieguvumu taisnīgu sadali starp visiem sabiedrības locekḷiem, īpaši tiem, kuri valsts reformu vai krǐžu dēḷ cieš zaudējumus. Lìdzīgi - institūcijas, kuras ir atbildīgas par valsts atbalstu sniegšanu uzṇēmumiem krīzes laikā, var kḷūt par šḳērsli inovatīvu jaunuzṇēmumu izaugsmei un tālāk jau visai valsts ekonomiskajai attīstîbai.

Ekonomiskajā un politiskajā analīzē institūciju ietekme uz indivīdu rīcību bieži tiek ignorēta. Tam ir vairāki iemesli. Pirmkārt, būdamas abstraktas konstrukcijas, institūcijas politiku vidē nereti nav tieši saskatāmas - tās kḷūst "redzamas", tikai veicot salīdzinošu analīzi starp valstīm vai laika periodiem. Otrkārt, institūciju analīze ir sarežğîts process, kuras laikā ir jāiegūst un no dažādu disciplīnu viedokḷa jāinterpretē plašs informācijas klāsts. ${ }^{11}$ Tomēr pastāv institūciju analīzes un efektivitātes novērtējuma koncepcija.

Institūciju analīzes un attīstības ietvars (angliski - Institutional Analysis and Development jeb IAD) ir konceptuāls rīks institūciju izpētei, izdalot dažādas

\footnotetext{
9 Acemoglu, D. (2009). Introduction to Modern Economic Growth. Princeton University Press, 158-159.

10 Polski, M. M., Ostrom, E. (2017). An Institutional Framework for Policy Analysis and Design. In: Elinor Ostrom and the Bloomington School of Political Economy: A Framework for Policy Analysis, Vol. 3 (Lexington Books), 14.

11 Turpat.
} 
institūciju darbību ietekmējošo faktoru grupas un l̦aujot izsekot lēmumu pieņemšanas procesiem ${ }^{12}$ institūciju iekšienē un izprast, kāpēc indivīdi institūciju ietvarā rīkojas tā un ne citādāk. ${ }^{13}$ Kā norāda IAD ietvara nosaukums, runa ir arī par institūciju attīstību jeb transformācijām laika gaitā, kam par iemeslu ir dalībnieku mācišanās un pielāgošanās - attiecīgi institūciju pārmaiṇas primāri tiek uzlūkotas kā endogēns process (2. attēls). Institūcijas ietekmē arī dažādi ārēji (eksogēni) faktori, pār kuriem institūciju dalībniekiem nav nekādas kontroles, piemēram, nodrošinājums ar resursiem, pieejamās tehnologijas un prasmes, starptautiskā situācija u. tml. Tāpat institūciju darbību ietekmē arī jau pastāvošās formālās institūcijas (statūti, procedūru reglamenti, priekšraksti u. tml.) un neformālās institūcijas (vispārēji morāles priekšstati par to, kas ir pareizi un kas - ne). Ne mazāk svarīgs ir lomu sadalījums starp indivīdiem-dalïbniekiem, šo dalïbnieku personības, kā arī izpratne par institūcijas uzdevumiem, sasniedzamajiem mērḳiem, pastāvošajiem ierobežojumiem un rīcibas alternatīvām. Pareizi artikulēti un dalïbnieku izprasti formālie noteikumi efektīvi izslēdz viena veida (nevēlamās) rīcỉbas alternatīvas un iespējo cita veida (vēlamas) alternatīvas, turklāt būtiska ir arī labvēlīga mikrovide indivīdu mijiedarbībai, jo ḷauj pārvarēt indivīdu raksturu nesaderības izaicinājumu. Gan institūciju konteksts, gan mikrovide nav statiski un laika gaitā mainās. Proti, tas ir atkarīgs no jau pieminētajiem mācǐšanās un pielāgošanās procesiem institūciju iekšienē - viena cikla iznākums atstāj ietekmi uz nākamo ciklu, veidojot atgriezeniskās saites cilpu. Jo efektīvāka ir iznākumu novērtēšana, jo efektīvāka un mērḳtiecīgāka ir dalībnieku mācǐšanās un pielāgošanās. Indivīdu pielāgošanās var notikt gan spontāni, gan reglamentēti. No spontānas pielāgošanās pilnībā izvairīties nav iespējams, taču pārmērīga spontanitāte var būt destruktīva, tāpēc ilgtspējīgu institucionālo elastīgumu nodrošina tikai reglamentēta pielāgošanās, grozot iekšējos noteikumus un/vai ārējo normatīvo bāzi. ${ }^{14}$

Institūciju analīzei ir svarīgi četri papildu aspekti. Pirmkārt, institūcijas pastāv dažādās formās, piemēram, kā stratēgijas, normas un noteikumi. ${ }^{15}$ Noteikumi - atšḳirībā no stratēgijām un normām - satur sankciju elementu. Sankcijas var būt dažādas (piemēram, sods vai atlīdzība), taču no institūciju viedokḷa

12 Beach, D. Process-Tracing Methods in Social Science. Oxford Research Encyclopedia of Politics. Last viewed on 22 September 2020.

13 Polski, M. M., Ostrom, E. (2017). An Institutional Framework for Policy Analysis and Design. In: Elinor Ostrom and the Bloomington School of Political Economy: A Framework for Policy Analysis, Vol. 3 (Lexington Books), 14.

14 Hall, P. A., Thelen, K. (2007). Institutional Change in Varieties of Capitalism. Socio-Economic Review, January 2009, DOI: 10.1093/ser/mwn020.

15 Watkins, C., Westphal, L. M. (2016). People Don't Talk in Institutional Statements: A Methodological Case Study of the Institutional Analysis and Development Framework. The Policy Studies Journal, Vol. 44, No. S1, 102. 


\section{2. attēls. Institūciju analīzes un attīstības (IAD) vispārējā analīzes shēma}

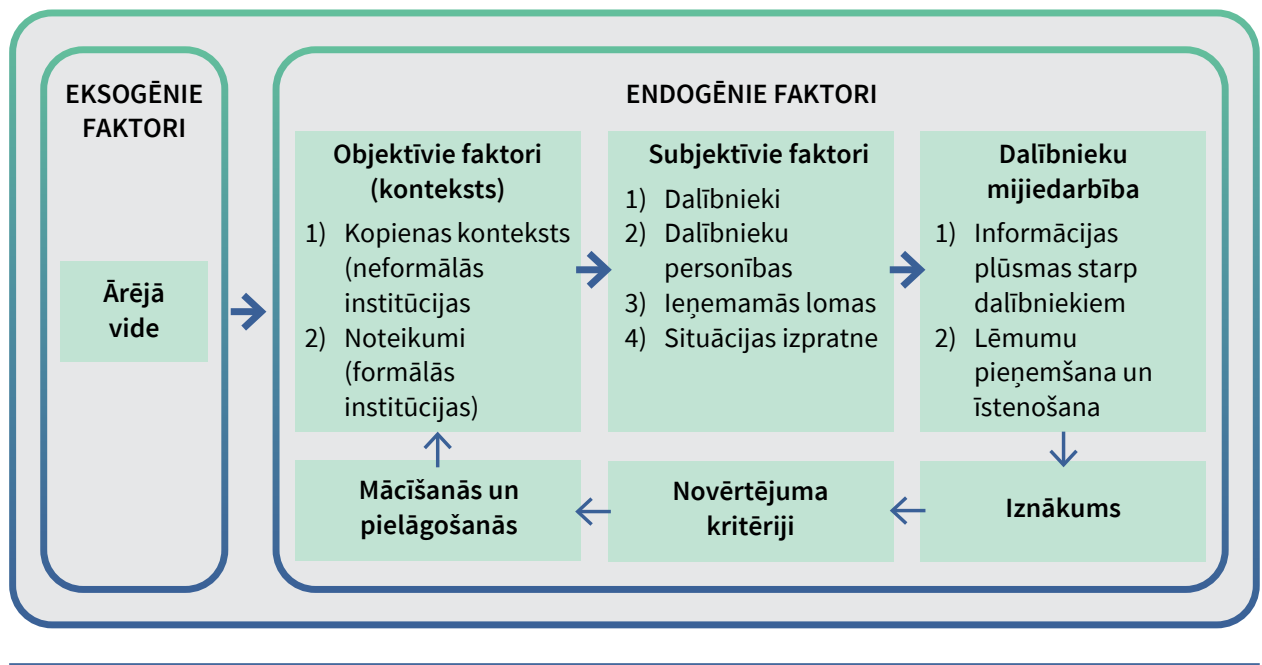

šo sankciju efektivitāte ir ļoti nozīmīga, jo ievirza indivīdu rīcỉbu vēlamajā gultnē. Laika gaitā stratēgijas var pārtapt noteikumos un, otrādi, noteikumi - stratēgijās. Pirmajā gadījumā var runāt par institucionalizācijas pastiprināšanos, otrajā - par pavājināšanos. Otrkārt, institūcijas var būt formālas un neformālas. Gadījumos, kad formālās institūcijas (reglamentos ietvertā publiskā morāle) nepārklājas ar neformālajām institūcijām (pilsonisko morāli), veidojas labvēlīgi apstākḷi nelegālām darbībām, tostarp ēnu ekonomikai un zemai nodokḷu disciplīnai. ${ }^{16}$ Treškārt, par organizāciju pārmaiṇu dziļumu liecina tas, vai pārmaiṇas skar tikai organizācijas operatīvo institūciju līmeni (ikdienas procesi) vai arī pārējo divu augstāko - vadības un konstituēěanās - līmeņu institūcijas. Par fundamentālām pārmaiņām var runāt tikai tad, kad pārmaiņas ir skārušas konstituēšanās līmeni, jo tās reglamentē organizācijas būtību, mērḳus un principus. Ceturtkārt, mēǵginājumi veidot vai reformēt institūcijas tam nepiemērotā vidē (piemēram, ar copy-paste metodi) ir nolemti neveiksmei. Kontekstam ir nozīme, tāpēc, veidojot jaunas institūcijas, uzmanība ir jāpievērš tam, vai cerētais iznākums vispār ir objektīvi iespējams.

Politiku analīzē IAD ietvars var tikt izmantots divējādi: (1) gan kā esošo politiku efektivitātes diagnostikas instruments, (2) gan kā politiku plānošanas

16 Williams, C. C. \& Horodnic, I. A. (2015). Explaining and tackling the shadow economy in Estonia, Latvia and Lithuania: a tax morale approach. Baltic Journal of Economics, Baltic International Centre for Economic Policy Studies, Vol. 15(2), pp. 81-98. 
instruments. ${ }^{17}$ IAD ietvara priekšrocíba ir elastīgums, jo to var attiecināt tikpat labi uz mikrolīmeņa (atsevišķu normu), mezolīmeņa (uzņēmumu un iestāžu), cik uz makrolīmeņa (sektoru, nozaru vai nacionāla līmeņa) institucionālām formām. ${ }^{18}$ Tādējādi IAD ietvarā visa tautsaimniecība var tikt uzlūkota kā vienots institucionāls veidojums. Kā piemēru piedāvājam Latvijas valsts pārvaldes efektivitātes novērtējumu attiecībā uz Covid-19 pandēmijas krīzes un ilgtspējīgas attīstības vadību.

\section{Latvijas valsts pārvaldes efektivitāte Covid-19 pandēmijas krīzes laikā}

Šìs analīzes pamatā ir R. Baloža un E. Danovska pētījums par valsts konstitucionālo un administratīvo ietvaru pandēmijas un citu ārkārtēju situāciju efektīvai pārvaldībā ${ }^{19}$, Valsts kontroles situācijas izpētes ziṇojums par Covid-19 izplatîbas ierobežošanai nepieciešamo resursu nodrošinājumu valsts un pašvaldību institūcijās un sabiedriskās domas aptaujas rezultāti. ${ }^{20}$ Galvenie novērojumi ir strukturēti atbilstoši IAD shēmai.

Eksogēnie faktori:

1) Zināšanu un datu trūkums par vīrusu un infekcijas izplatības ātrums un mērogs.

2) Ar vīrusa izplatību saistītā geopolitika, tostarp dezinformācija.

3) Vakcīnu efektivitāte pret Covid-19 vīrusa jaunajiem paveidiem un piekḷuve vakcīnām, kas tiek īstenota caur Eiropas kopējo iepirkumu.

\section{Objektīvie endogēnie faktori}

- Kopienas konteksts:

1) Pēc pirmā pandēmijas viḷna (2020. gada septembrī) sabiedrībā valdīja augsta līdzcietība un solidaritāte, īpaši attiecībā uz neaizsargātākajiem sabiedrības locekḷiem: cilvēki atbalstìtu apjomīgāku valsts palīdzību krīzes laikā.

Aptaujas rezultāti (3. attēls) liecina, ka vairums respondentu $(50,6 \%)$ atbalstīja elastīgāku fiskālo politiku, proti, valsts atbalstam grūtībās nonākušajiem

Polski, M. M., Ostrom, E. (2017). An Institutional Framework for Policy Analysis and Design. In: Elinor Ostrom and the Bloomington School of Political Economy: A Framework for Policy Analysis, Vol. 3 (Lexington Books), 17.

18 Ostrom, E. (2005). Understanding institutional diversity (Princeton University Press: Princeton and Oxford), 58-62.

19 Balodis, R., Danovskis, E. Problems of the functionality of collegial government institutions during the COVID-19 pandemics and solutions for future. Journal of the University of Latvia "Law", Nr. 14 https:// www.journaloftheuniversityoflatvialaw.lu.lv/zinas/zina/t/56216/...

20 Austers, A., N̦ikišins, J. (2020, septembris). Sabiedriskās domas aptaujas rezultātu apkopojums. 


\section{3. attēls. Respondentu skatījums uz vērtībām pandēmijas krīzes kontekstā (procentos)}

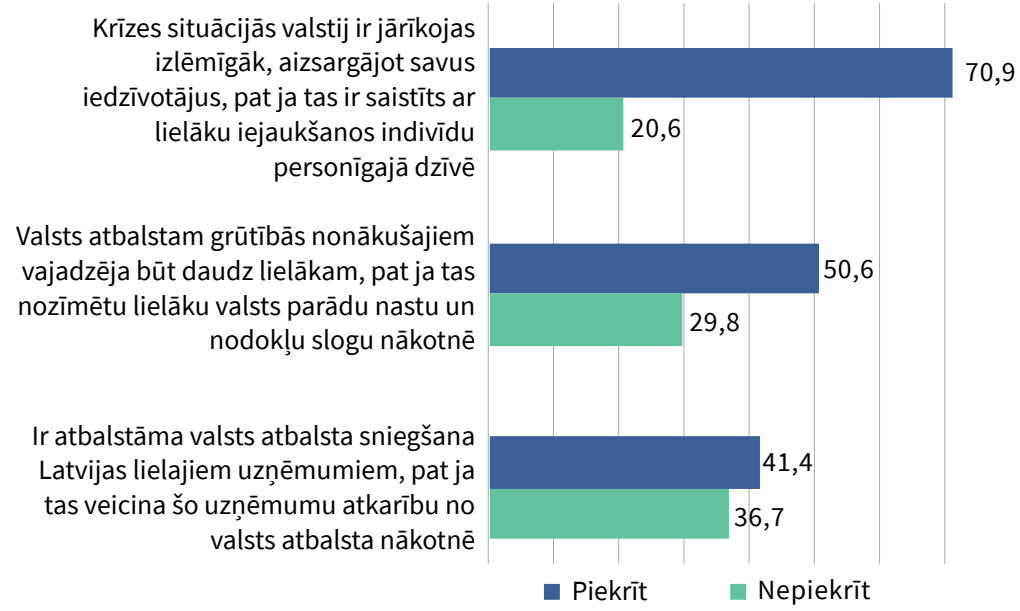

vajadzēja būt daudz lielākam, pat ja tas nozīmētu lielāku valsts parādu nastu un nodokḷu slogu nākotnē; 41,4\% uzskatīja, ka ir nepieciešama valsts atbalsta sniegšana Latvijas lielajiem uzṇēmumiem.

2) Sabiedrība atbalstīja lielāku valsts lomu tādu pandēmijas izraisītu krīžu risināšanā, kā Covid-19 un atkārtota Covid-19 pandēmijas izplatības viḷņa gadījumā atbalstītu tikpat stingrus vai pat stingrākus cilvēku savstarpējās kontaktēšanās ierobežojumus, pat samierinoties ar fundamentālu liberālas valsts vērtību - indivīda brīvība un personiskās dzīves neaizskaramība - ierobežojumiem.

Aptauja atklāja, ka septembrī 70,9\% iedzīvotāju uzskatīja, ka krīzes situācijās valstij būtu jārīkojas izlēmīgāk, pat ja tas būtu saistīts ar lielāku iejaukšanos indivīdu personīgajā dzīvē (3. attēls).

ESAO analīze ${ }^{21}$ parāda, ka atsevišḳu valstu gadījumos pastāv saikne starp uzticēšanās līmeni valdībai un saslimstības rādītājiem, jo valdībām, kurām ir zemāka uzticības pakāpe, ir grūtības īstenot ierobežojošus pasākumus. Latvijā sabiedrības aptauja atklāja, ka 63,5\% respondentu uzskatīja, ka atkārtota Covid-19 pandēmijas izplatības viḷna gadījumā būtu jāievieš tikpat stingri vai pat stingrāki cilvēku savstarpējās kontaktēšanās ierobežojumi (4. attēls). Starp tiem respondentiem, kuri bija riska grupā, atbalsts stingrākiem ierobežojošiem

${ }^{21}$ OECD. The territorial impact of COVID-19: Managing the crisis across levels of government. 10 November, 2020 http://www.oecd.org/coronavirus/policy-responses/the-territorial-impact-of-covid-19-managingthe-crisis-across-levels-of-government-d3e314e1/. 76-77. 


\section{4. attēls. Atbalsts stingrākiem ierobežojošiem pasākumiem atkārtota pandēmijas viḷna gadijumā (procentos)}

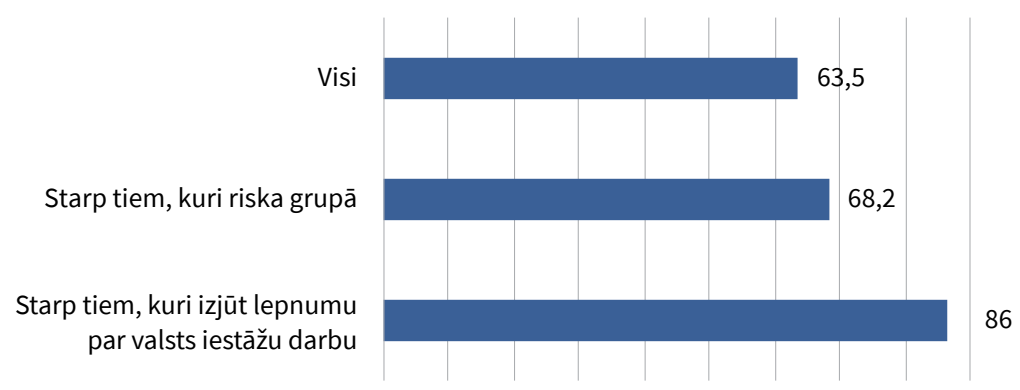

pasākumiem bija vēl lielāks - 68,2\%; starp tiem, kuri izjuta lepnumu par valsts iestāžu līdzšinējo darbu, - pat 86 procenti. Tas liecina par ievērojamu sabiedrības uzticēšanos valdības darbam pirmā pandēmijas viḷna laikā.

- Noteikumu konteksts:

1) Latvijā pandēmijas apstākḷi un ārkārtējā situācija nebija radījusi tādus izaicinājumus valsts pārvaldei, kuri nebūtu atrisināmi esošā tiesiskā regulējuma ietvaros, tomēr krīzes situācijā atsevišḳās jomās (piemēram attālinātais darbs) bija nepieciešama normatīvās vides pilnveidošana;

2) trūka konstitucionāla regulējuma ārkārtējām situācijām, kas radīja tiesvedības riskus saistībā ar fundamentālo brīvību ierobežošanu;

3) Latvijā Covid-19 pandēmija tika sagaidīta bez spēkā esoša, uz katastrofu risku novērtējumu balstīta detalizēta Valsts civilās aizsardzības plāna.

\section{Subjektīvie endogēnie faktori un mijiedarbība}

- Subjektivie faktori:

1) pirmās ārkārtējās situācijas laikā par katastrofu pārvaldīšanu atbildīgajām institūcijām nebija pietiekamas izpratnes par valsts materiālo rezervju plānošanas principiem. Faktiski netika pārvaldīta informācija par individuālo aizsardzības līdzekḷu pieejamību institūciju rīcībā, kā arī nebija izveidota efektīva sistēma individuālo aizsardzības līdzekḷu pieprasījuma prognozēšanai;

2) nebija detalizēti noteikti katastrofu pārvaldīšanas pasākumi un to istenotāji;

3) bija decentralizēta pieeja Covid-19 izplatības mazināšanas pasākumiem, jo par resursu plānošanu, pietiekamību un vajadzību nodrošināšanu bija atbildīga katra pašvaldība un katra institūcija. 
- Dalībnieku mijiedarbība:

1) tā kā normatīvie akti neparedzēja kritērijus iesaistīto institūciju noteikšanai, nekonkretizēja, kādi ir apgādes koordinatora pienākumi u. c., iestādēm izveidojās atšķirīga izpratne par epidemiologiskās situācijas vadībā iesaistītajām institūcijām;

2) valsts iestādes spēja nodrošināt valsts funkciju darbības nepārtrauktību un juridiski adekvātu krīzes vadību, pat par spīti tam, ka trūka konstitucionāla regulējuma ārkārtējām situācijām.

\section{Endogēnie faktori - iznākums un atgriezeniskās saites cilpa}

- Institucionālais iznākums:

1) iestādēs kritiskas situācijas ar individuālo aizsardzības līdzekḷu nodrošināšanu netika piel̦autas, tomēr informācijas un vienotas izpratnes trūkums radija būtisku papildu darba slogu;

2) sabiedrības vairākums pozitīi novērtēja valsts iestāžu darbu un īstenotās valsts atbalsta programmas un solidarizējās ar neaizsargātākajiem sabiedrības locekliem.

2020. gada septembrī 51,6\% respondentu piekrita apgalvojumam, ka valsts ārkārtas finansiālais atbalsts palīdzēja uzņēmējiem pārvarēt krīzi, mazliet mazāk - 45,3\% - ka tā bija palīdzējusi valstij (5. attēls). Zīmīgi, ka visās respondentu grupās ārkārtas atbalsta nozīmi uzṇēmējiem vērtēja augstāk nekā valstij kopumā. Valsts atbalsta efektivitāte attiecībā uz uzṇēmējiem vispozitīvāk tika novērtēta pensionāru (60,8\%), latviešu (57,3\%) un valsts sektorā strādājošo vidū (57\%). Arī laukos $(58,5 \%)$ un Vidzemē dzīvojošie $(61,3 \%)$ bija vairāk tendēti vērtēt pozitīvi valsts programmu ietekmi uz uzṇēmējiem. Lìdzīga aina bija vērojama arī attiecībā uz valsts atbalsta ietekmi uz valsti: pensionāru, latviešu, valsts sektorā strādājošo, laukos un Vidzemē dzīvojošo vidū pozitīvo vērtējumu bija vairāk.

\section{5. attēls. Sabiedrības vērtējums par valsts ārkārtas programmām (procentos)}

Vērtējot kopumā, valsts sniegtais ārkārtas atbalsts palīdzēja UZN̦ĒMUMIEM sekmīgāk pārciest ekonomiskās grūtības

Vērtējot kopumā, sniegtais valsts ārkārtas atbalsts bija pietiekami efektīvs un palīdzēja VALSTIJ sekmīgāk pārciest ekonomiskās grūtības

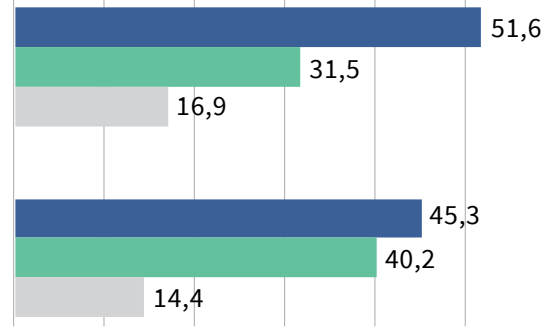

Piekrītu Nepiekrītu Grūti pateikt/NA 


\section{6. attēls. Respondentu attieksme pret valsts iestāžu darbu (procentos)}

Es personīgi izjūtu lepnumu par valsts iestāžu darbu
Covid-19 pandēmijas laikā un par šā darba rezultātiem

Ārkārtējās situācijas dēḷ valsts pārvalde savas funkcijas spēja pildīt tāpat kā iepriekš vai vēl labāk

Ārkārtējās situācijas dēḷ radītās attālinātā darba formas valsts pārvaldi ir padarījušas modernāku un pieejamāku privātpersonām

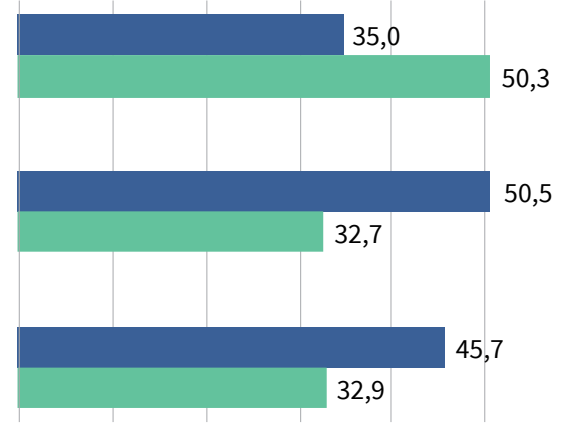

Piekrīt Nepiekrīt

Aptaujā tika mēǵināts arī noskaidrot, vai starp tiem respondentiem, kuri saņēma valsts ārkārtas palīdzību, vērtējums par šo programmu efektivitāti bija labāks, taču pārliecinošu atbildi neizdevās iegūt - lai arī respondentu atbildes uzrādīja, ka starp atbalstu saṇēmušajiem pozitīvu vērtējumu par valsts programmām bija relatīvi vairāk, šì kopsakarība nebija statistiski nozīmīga.

Puse (50,5\%) aptaujāto piekrita apgalvojumam, ka valsts ārkārtējās situācijas dēl savas funkcijas spēja pildīt tikpat labi vai pat labāk (6. attēls). Vislielākais atbalsts šādam uzskatam bija jauniešu un senioru vidū (starp 53 un 57\%), respondentu vidū ar augstāko izglìtību (57,4\%), ǵimenēs bez bērniem (53,7\%), vidēju ienākumu grupās (starp 53 un 58\%).

Viedoklim, ka ārkārtējās situācijas dēḷ radītās attālinātā darba formas valsts pārvaldi ir padarījušas modernāku un pieejamāku privātpersonām, piekrita 45,7\% respondentu Šādam viedoklim vairāk sliecās piekrist uzṇēmēji (56,5\%), respondenti ar lielām ǵimenēm (starp 48 un 50\%), vidējas paaudzes respondenti $(48,5 \%)$ un privātajā sektorā strādājošie $(48,3 \%)$.

Aptuveni trešā dal̦a (35\%) respondentu apstiprināja, ka izjūt lepnumu par šo valsts iestāžu darbu pandēmijas laikā. Lepnuma sajūta bija izteiktāka pensionāru (45,3\%), valsts sektorā strādājošo (40,8\%), respondentu ar augstāko izglītību un latviešu vidū (39,5 un 39,5\%). Datu analīze parāda, ka starp tiem respondentiem, kuri atrodas riska grupā, lepnums par valsts iestāžu darbu ir bijis nedaudz izteiktāks. $^{22}$

22 Spīrmana (Spearman) korelācijas koeficients starp atrašanos riska grupā un lepnumu par valsts iestāžu darbu ir 0,11 (pie statistiskās nozīmības līmeņa 0,016), kas liecina par vāju, bet pozitīvu korelāciju, $n=807$. 


\section{7. attēls. Nacionālo valdību īstenoto pasākumu pandēmijas ierobežošanai vērtējums Eiropas Savienības dalībvalstīs (procentos)}

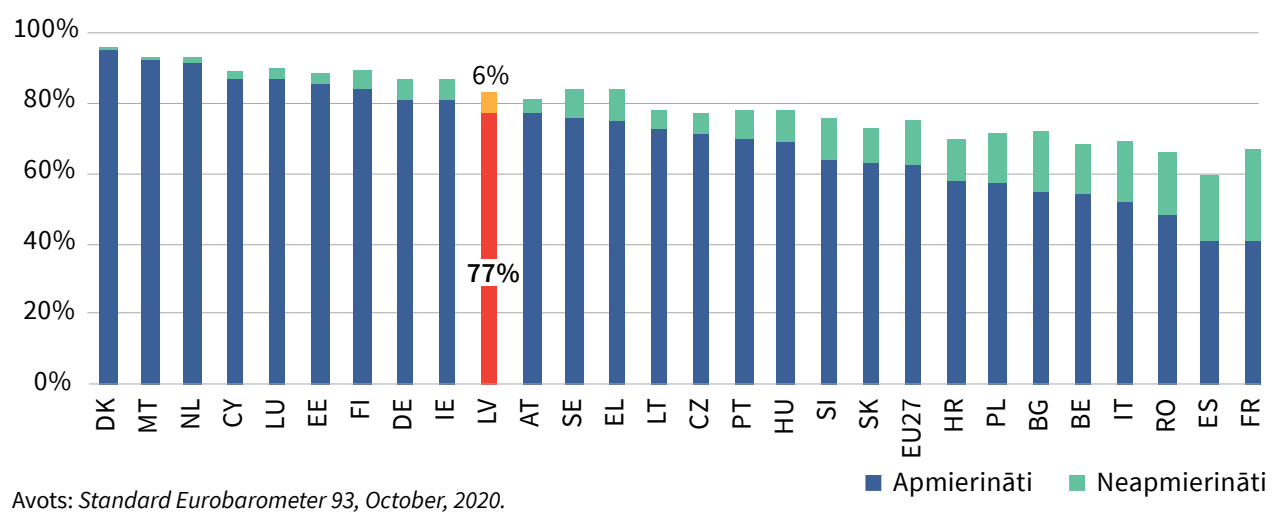

Salīdzinājumam - Eirobarometra aptauja, kas tika veikta jūlijā un augustā, parāda, ka Latvijā 77\% bija apmierināti ar valdības darbu pandēmijas laikā (7. attēls). Šie dati gan nav tieši salīdzināmi ar reCOVery aptauju, taču l̦auj spriest par valdības darba vērtējumu salīdzinājumā ar citām ES dalībvalstīm - Latvijai ir 10. labākais vērtējums.

3) Decembrī salīdzinājumā ar septembri sabiedrības noskaņojums bija jūtami pasliktinājies visās sociāldemogrāfiskajās grupās.

Pirmā viļ̣na laikā pandēmija nebija būtiski atsaukusies uz sabiedrības apmierinātību ar dzīvi. Piemēram, salīdzinājumā ar identisku aptauju, kas īstenota pirms pandēmijas 2019. gada janvārīîn, bija redzams, ka rādītāji ir ḷoti līdzịgi (1. tabula). Iespējams, ka neilgi pirms pandēmijas sabiedrības noskaņojums bija uzlabojies, taču ārkārtējās situācijas laikā tas sāka pasliktināties, taču nenoslīdot zem 2019. gadā novērotā apmierinātības līmeņa.

Decembrī salīdzinājumā ar septembri sabiedrības noskaṇojums ${ }^{24}$ bija jūtami pasliktinājies: septembrī vidējais aritmētiskais apmierinātības ar dzīvi rādītājs sasniedza 6,8 punktus, decembrī - tikai 6,4 punktus. 8. attēlā ir redzams, ka decembra vērtējumu līkne ir plakanāka, turklāt negatīvo vērtējumu zonā (zem 6) tā ir virs septembra lìknes, pozitīvo (virs 6) - zem septembra lìknes.

23 Kaprāns, M., Mieriņa, I. (2019). Ideological polarization in Baltic societies. Riga: Institute of Philosophy and Sociology, University of Latvia.

24 Austers, A., N̦ikišins, J. Sabiedriskās domas aptaujas rezultātu apkopojums. Septembris (2020) un decembris (2021). 
1. tabula. ledzìvotāju apmierinātība ar dzīvi pēc ienākumiem un dzīvesvietas*

\begin{tabular}{|l|c|c|c|c|c|c|c|c|c|}
\hline & \multicolumn{4}{|c|}{2020. gada septembris } & \multicolumn{3}{|c|}{ 2019. gada janvāris** } \\
\hline $\begin{array}{c}\text { Mēneša vid. ienāk. uz } \\
\text { 1 mājsaimn. locekli }\end{array}$ & Bāze & $\begin{array}{c}\text { Vid. } \\
\text { aritm. }\end{array}$ & St. nov. & Mediāna & Bāze & $\begin{array}{c}\text { Vid. } \\
\text { aritm. }\end{array}$ & St. nov. & Mediāna \\
\hline Līdz 249 EUR & 165 & 5,89 & 1,84 & 6 & 183 & 5,97 & 1,99 & 6 \\
\hline 250-310 EUR & 166 & 6,71 & 1,8 & 7 & 187 & 6,29 & 1,78 & 6 \\
\hline 311-430 EUR & 173 & 6,62 & 1,6 & 7 & 180 & 6,68 & 1,83 & 7 \\
\hline 431-600 EUR & 207 & 7,08 & 1,45 & 7 & 178 & 6,86 & 1,55 & 7 \\
\hline 601 EUR un vairāk & 140 & 7,29 & 1,48 & 7 & 144 & 7,57 & 1,47 & 8 \\
\hline Regions & 325 & 6,96 & 1,6 & 7 & 323 & 6,95 & 1,77 & 7 \\
\hline Rīga & 190 & 7,01 & 1,65 & 7 & 186 & 6,77 & 1,87 & 7 \\
\hline Pierīga & 101 & 6,3 & 1,72 & 6 & 99 & 6 & 1,71 & 6 \\
\hline Vidzeme & 127 & 6,8 & 1,82 & 7 & 127 & 6,79 & 1,45 & 7 \\
\hline Kurzeme & 120 & 6,84 & 1,64 & 7 & 121 & 6,5 & 2,15 & 7 \\
\hline Zemgale & 143 & 6,62 & 1,65 & 7 & 139 & 6,63 & 1,79 & 7 \\
\hline Latgale & & & & & & & & \\
\hline
\end{tabular}

* Abās aptaujās respondentiem tika lūgts sniegt dzīves apmierinātības vērtējumu 10 punktu skalā, kur 1 nozīmēja pilnīgu neapmierinātību un 10 - pilnīgu apmierinātību.

** Kaprāns, M., Mieriņa, I. (2019). Ideological polarization in Baltic societies. Riga: Institute of Philosophy and Sociology, University of Latvia.

\section{8. attēls. Sabiedrības apmierinātība ar dzīvi (procentos)}

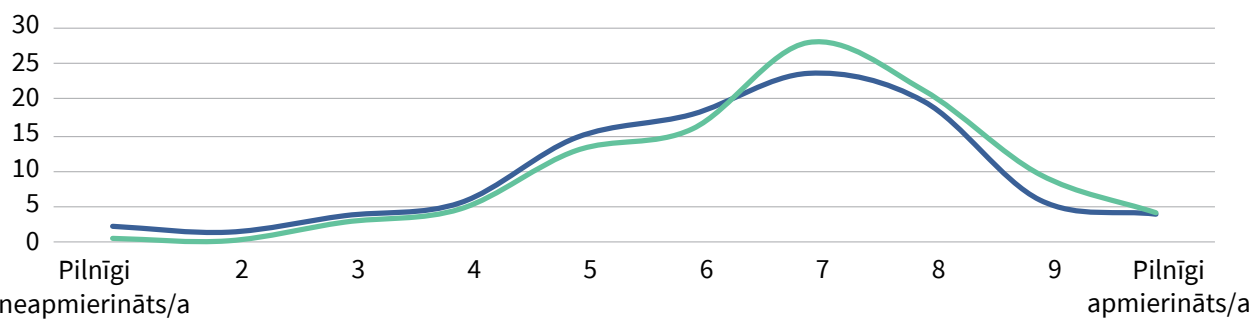

2020. gada decembris 2020 . gada septembris 
- Novērtējuma kritēriji:

1) institūciju spēja ātri reagèet, pastiprināti koordinēt savas darbības un savstarpēji sadarboties;

2) efektīva pārvaldība visos valdības lìmeņos - gan centrālajā, gan vietējā, tā veicinot sabiedrības uzticēšanos valsts pārvaldei;

3) centralizēti krīzes vadības risinājumi, nostiprinot valdības lomu;

4) efektīvas operatīvās koordinācijas nodrošināšana, pārraugot rīcības plānus un tajos norādīto mērķu sasniegšanu;

5) sabiedrības uzticēšanas valsts pārvaldei.

Latvijas publiskās pārvaldes atbilstību novērtējuma kritērijiem dal̦ēji ilustrē sabiedrības domas aptauja par uzticēšanos demokrātijai, Latvijas valdībai un Eiropas Savienībai.

To, ka pandēmijas laikā ir pieaugusi uzticēšanās demokrātijai, atzina $27,1 \%$ aptaujāto ${ }^{25}$ (9. attēls). Salīdzinoši augsts atbalsts šādai nostājai bija vecākās paaudzes iedzīvotāju (virs 30\%) un Vidzemē $(44,8 \%)$ dzīvojošo vidū, viszemākais - starp mājsaimniecēm $(8,7 \%)$, bezdarbniekiem $(16,2 \%)$ un Kurzemē dzīvojošajiem (17,4\%). To respondentu loks, kuri uzskatija, ka viņi viedoklim Latvijā ir nozīme, ir daudz zemāks - tikai 18,5 procenti. Apstiprinoši visbiežāk atbildēja respondenti ar augstāko izglìtỉbu (25,1\%), vidējās paaudzes iedzivotāji (24\%) un valsts sektorā strādājošie (22,6\%), visretāk - bezdarbnieki (4,7\%), iedzīvotāji ar zemiem ienākumiem (10\%) un Latvijas nepilsoṇi (10,5\%). Pa reǵioniem visaugstākais pašapziņas līmenis bija Latgalē (24,2\%), viszemākais - Kurzemē (9,1\%).

\section{9. attēls. Respondentu attieksme pret demokrātiju (procentos)}

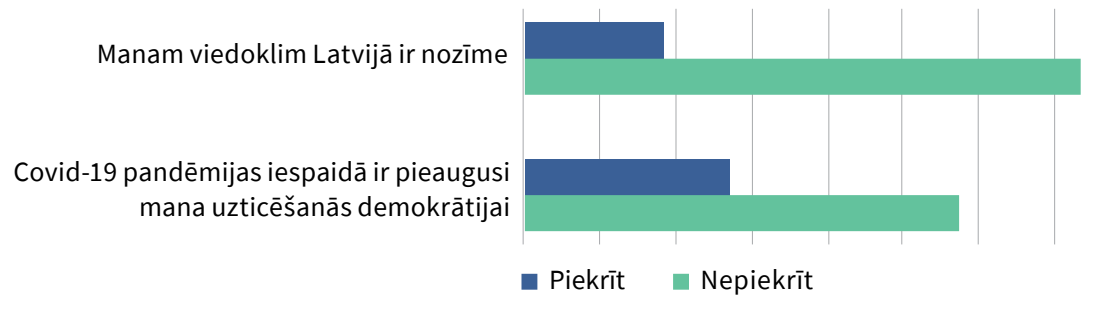

Salīdzinājumā ar citām ES dalībvalstīm 2020. gada oktobrī Latvijā sabiedrības apmierinātība ar demokrātiju bija salīdzinoši augsta, taču sabiedrības

25 Austers, A., N̦ikišins, J. (2020, septembris). Sabiedriskās domas aptaujas rezultātu apkopojums. 


\section{0. attēls. Sabiedrības viedoklis par demokrātijas darbību un pilsoṇu ietekmi ES dalïbvalstīs (procentos)}

a) viedoklis par demokrātijas darbību

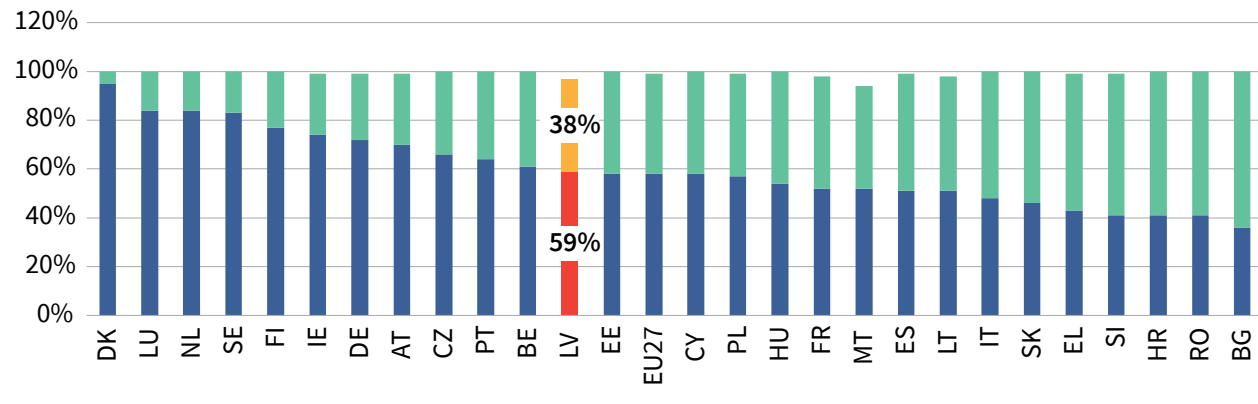

n Apmierināti neapmierināti

b) pilsoņu viedokḷu ietekme uz valsti

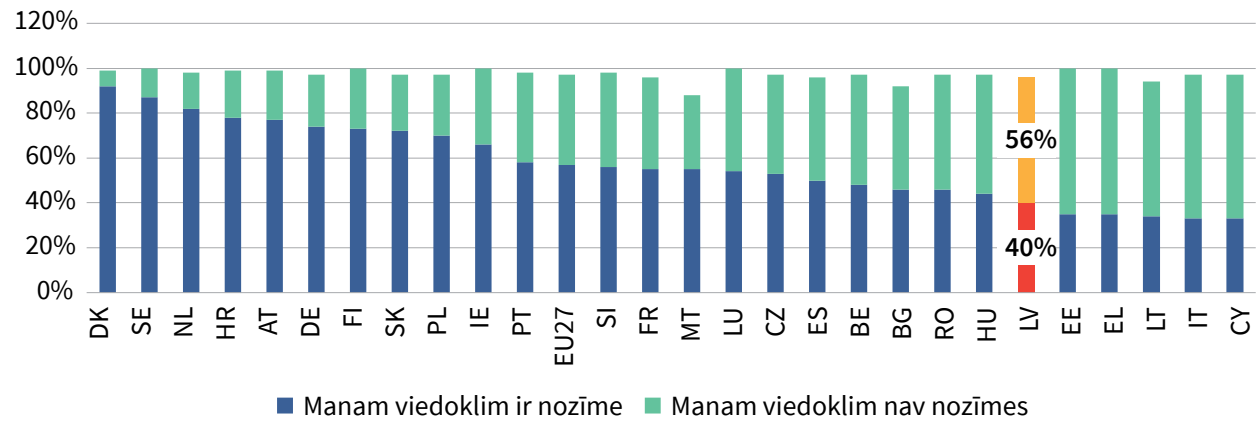

Avots: Standard Eurobarometer 93, October, 2020.

pašapziņa, kas izpaužas vērtējumā par indivīdu ietekmi uz valsti, bija viena no zemākajām (10. attēls).

Pandēmijas pirmā viḷna laikā uzticēšanās valsts institūcijām bija pieaugusi 10 procentos gadījumu un samazinājusies 17,3 procentos gadijumu, kas liecina par pieaugošu vilšanos valsts institūcijās (11. attēls). Uzticēšanā vislielākā mērā bija zaudēta iedzīvotāju vidū ar pamatizglīīibu $(-18,8 \%)$, ar zemiem ienākumiem $(-15,1 \%)$, bezdarbnieku un mājsaimnieču vidū $(-14 \%)$, starp privātajā sektorā strādājošajiem $(-10,2 \%)$ un gimenēs ar bērniem $(-10,1 \%)$. Visdramatiskākais uzticības kritums bija Zemgalē (-33\%). Mēreni pozitīva viedokḷu korelācija bija novērojama starp piekrišanu apgalvojumam, ka valsts ārkārtas atbalsts bija pietiekami efektīvs un palīdzēja valstij sekmīgāk pārciest ekonomiskās grūtības, un 
11. attēls. letekme uz uzticēšanos Latvijas un Eiropas Savienības institūcijām (procentos)

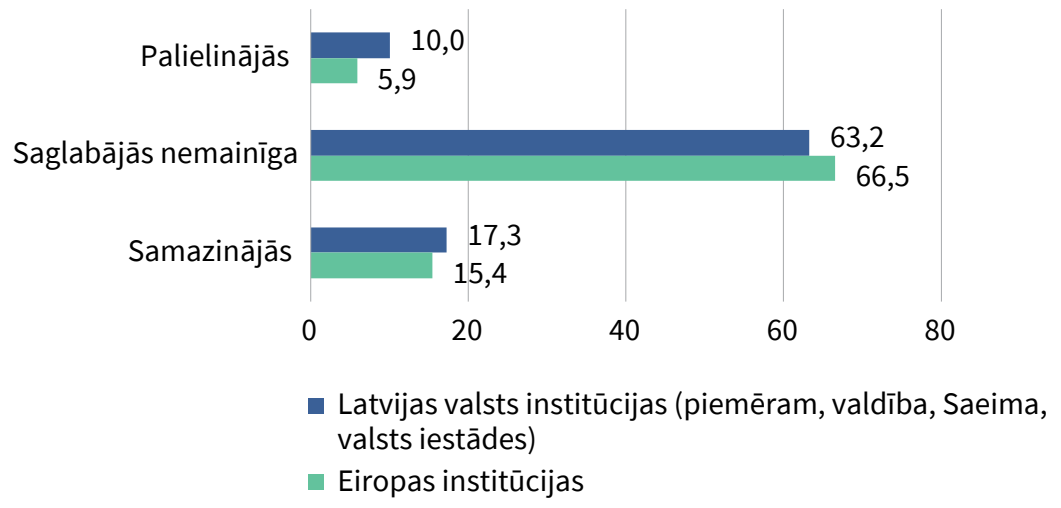

uzticēšanās pieaugumu valsts institūcijām. ${ }^{26}$ Arī cilvēki, kuri atradās riska grupā, bija tendēti nedaudz vairāk uzticēties valsts institūcijām. ${ }^{27}$

Pandēmija bija sekmējusi uzticēšanās kritumu arī ES institūcijām, turklāt lielākā mērā nekā valsts institūcijām. Attiecībā uz ES institūcijām starpība starp respondentiem, kuri uzticas un kuri - ne, bija mīnus 9,5 procentpunkti. Uzticēšanās ES institūcijām bija īpaši zema bezdarbnieku (-20\%) un Zemgalē dzīvojošo vidū $(-16,9 \%)$. Neuzticēšanās ES institūcijām ir vairāk izplatīta iedzīvotāju vidū bez ğimenes - šie iedzīvotāji ir vairāk tendēti uzticēties valsts institūcijām.

Iedzīvotāju uzticēšanās izmainas institūcijām pandēmijas ietekmē ir jāvērtē kontekstā ar vispārējo uzticēšanās līmeni. Piemēram, Eiropas Komisijas Eirobarometra dati parāda, ka 2020. gada oktobrī Latvijā sabiedrības uzticēšanās ES institūcijām bija daudz lielāka nekā nacionālajām valsts institūcijām (12. attēls), līdz ar to, lai arī uzticības kritums ES institūcijām ir noticis visbiežāk, vairums Latvijas sabiedrības (54\%) tomēr joprojām daudz vairāk uzticas ES institūcijām nekā nacionālajām institūcijām (35\%). Viedoklim, ka bez ES atbalsta Latvija nebūtu spējusi sekmīgi ierobežot pandēmiju, piekrita 51,9\% respondentu, $61,6 \%$ uzskatīja, ka cīnu pret pandēmiju labāk īstenot ES līmenī.

Latvijas sabiedrības apmierinājums ar valdības politiku krīzes apkarošanā īpaši pasliktinājās 2021. gadā. Kā liecina Eirobarometra dati, Latvijā 2021. gada 1. ceturksnī tikai $21 \%$ no respondentiem bija apmierināti ar valdības rīcỉbu - zemākais

26 Spīrmana (Spearman) korelācijas koeficients starp abām respondentu grupām ir 0,38 (pie statistiskās nozīmības līmeṇa 0,000), kas liecina par mērenu korelāciju, $n=801$.

27 Spīrmana (Spearman) korelācijas koeficients starp abām respondentu grupām ir 0,12 (pie statistiskās nozīmības līmeņa 0,000), kas liecina par vāju korelāciju, $n=858$. 


\section{2. attēls. Sabiedrības uzticēšanās valsts pārvaldes institūcijām Eiropas Savienības dalībvalstīis ${ }^{28}$}

a) nacionālās valsts institūcijas

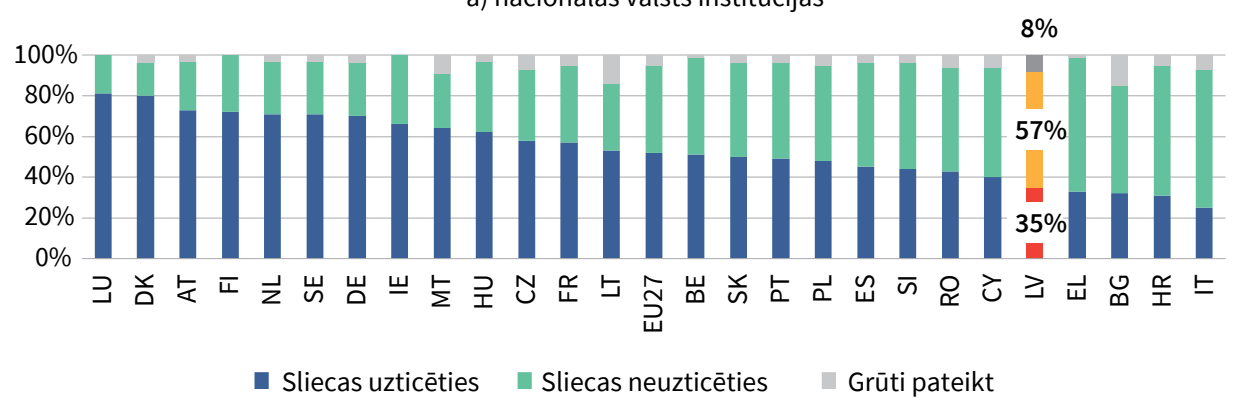

b) ES institūcijas

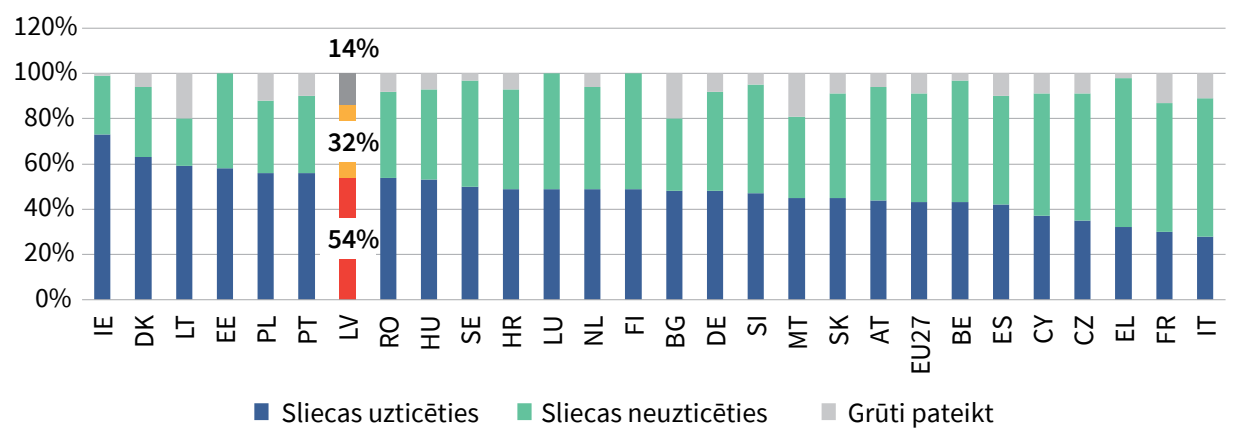

Avots: Standard Eurobarometer 93, October, 2020.

rādītājs ES, arī apmierinājuma kritums bijā vislielākais - 56\% kopš 2020. gada vasaras (avots: Standard Eurobarometer 94, April, 2020).

- Mācīšanās un pielāgošanās:

Valsts kontrole secināja, ka Latvijā vēl attīstās izpratne par Covid-19 izplatības ierobežošanai nepieciešamajiem sadarbības mehānismiem starp politisko vadību, publisko pārvaldi un citām institūcijām. Mācīšanās un pielāgošanās procesa efektivitāte varētu tikt novērtēta pēc krīzes.

Valsts pārvaldes efektivitātes novērojumi krīzes laikā apkopoti 13. attēlā.

28 Eirobarometra dati nav tieši salīdzināmi ar reCOVery-LV aptaujas datiem, jo atšķiras respondentu kopas atlases kritēriji. 
13. attēls. Valsts pārvaldes efektivitātes novērtējums Covid-19 pandēmijas krīzes laikā

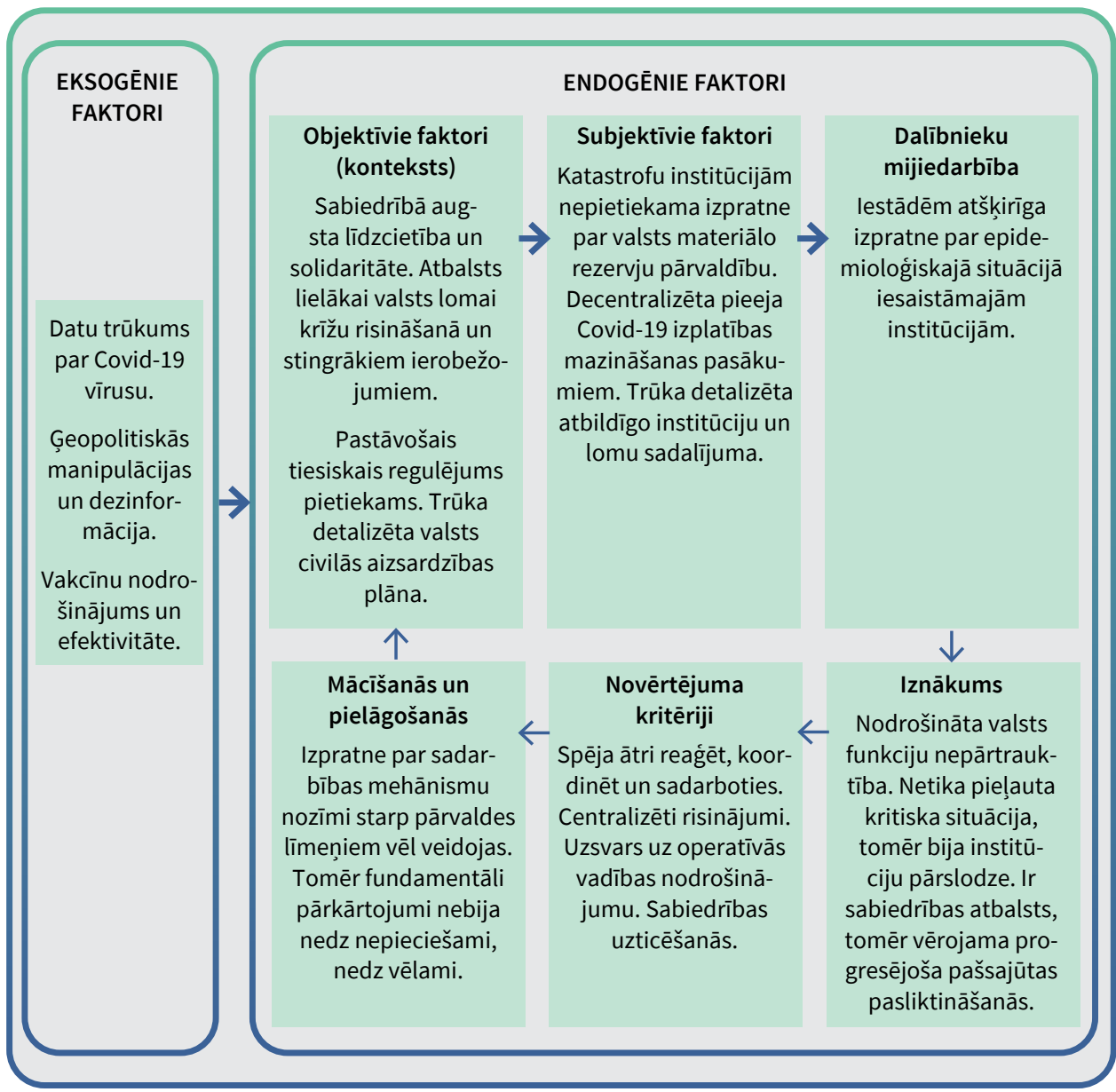

\section{Latvijas ilgtspējīgas attīstības vadības izaicinājumi}

Ilgtspējas princips ir saprotams kā centieni apvienot un līdzsvarot dažādas, līdz šim atsevišḳi uztvertas jomas: valsts ekonomisko izaugsmi, sabiedrības sociālo drošību, vides aizsardzību un kultūras attīstību. ${ }^{29}$

Valstu lēnas ekonomiskās izaugsmes cēloṇi nereti ir saistīti ar vāju starpinstitūciju un starpresoru darbības koordināciju un slikti funkcionējošiem pārdales mehānismiem, kuriem būtu jānodrošina atlīdzība arī tām sabiedrības grupām,

29 Litvins, G., Gailīte, D. (2015). Vai ilgtspēja kḷūs par jaunu vispārējo tiesību principu. Jurista Vārds, 4. aug. 
kuras zaudē reformu procesā un tāpēc pretojas reformām. Taču pētījumi arī demonstrē, ka daudzi attīstību ietekmējošie faktori - nodokḷu sistēma, izglīìiba, nevienlīdzība - ir endogēni, respektīvi, šo faktoru parametrus ir iespējams kalibrēt ar mērkstiecīgu valsts politiku palīdzību. ${ }^{30}$ Atbildes arī uz tādiem jautājumiem, kāpēc Latvijā tik maz tiek ieguldìts zinātnē un cilvēkresursu attīstībā un kāpēc nevedas ar inovāciju radīšanu un komercializāciju, ir jāmeklē institucionālajos procesos.

Kā norāda ESAO, lai politiskās un administratīvās sadrumstalotības apstākl̦os nodrošinātu ilgstošu ekonomisko izaugsmi, ir svarīgi ne tikai veidot politikas, kuras uzlabo ekonomisko spēēēāju motivāciju un prasmes pielāgoties mainīgajai videi, bet arī attīstìt institūcijas, kuras palīdz gan identificēt pareizākās rīcības virzienus, gan pārvarēt pretestību reformām un spēj efektīvi strādāt ar sabiedrību, pamatojot reformu nepieciešamību.$^{31}$ Pētỉjumi apliecina, ka valstīs, kuras ir nonākušas lēnas izaugsmes "slazdā", pamudinājumi atlikt reformas ir l̦oti spēcīgi: tie var būt politiska (politiķu īstermiṇa domāšana), tehniska (reformu izmaksu augstā koncentrācija pret ieguvumu izkliedētību un neparedzamību) un sociāla rakstura (politiskās elites rentes intereses). ${ }^{32}$ Institūciju pilnveidošana gan prasa lielas pūles un ir laikietilpīga. ${ }^{33}$

Tātad izaicinājumi ilgtspèjīgai attīstỉbai ir gan ekonomiska, gan politiska rakstura, un šo izaicinājumu sekmīga pārvarēšana ir lielā mērā atkarīga no tādu institūciju efektivitātes, kuras atbild par citu institūciju darbības koordināciju un efektivitāti, lai tādējādi iespējotu sinerğijas un novērstu neatbilstības starp šìm institūcijām. Taču, kā norāda pētnieki, jo vairāk attīstīta ir valsts, jo komplicētāka ir tās institucionālā struktūra, jo izaicinošāk ir nodrošināt attīstības procesu koordināciju. ${ }^{34}$

Starptautiskā pieredze liecina, ka būtiskākie faktori Covid-19 krīzes pārvarēšanā un atkopšanās vadībā arī ir efektīva pārvaldība, kas sevī ietver intensīvu darbības koordināciju starp dažādiem pārvaldes līmeṇiem un nozarēm, un institūciju elastīgums.

30 Alonso, J. A., Ocampo, J. A. (eds.). Trapped in the Middle? Developmental Challenges for Middle-Income Countries (Oxford Scholarship Online: November 2020). DOI:10.1093/oso/9780198852773.001.0001.

31 Banks, G. Institutions to promote pro-productivity policies: Logic and lessons. OECD Productivity Working Papers 2015-01, 2.

32 Gill, I. S., Homi, K. (2015). The Middle-Income Trap Turns Ten. World Bank Group Policy Research Working Paper, 740, 20.

33 Doner, R. F. Gaps in the trap: Neglected politics in middle-income trap analysis. OECD Development Matters. https:/oecd-development-matters.org/2021/01/11/gaps-in-the-trap-neglected-politics-in-middle- income-trap-analysis/. Last viewed on 21 March 2021.

34 Iammarino, S. et al. (2020). Falling into the Middle-Income Trap? A Study on the Risks for EU Regions to be Caught in a Middle-Income Trap. Final Report (European Commission), 86. 
14. attēls. Valsts regulācijas procesu kvalitātes indekss ESAO dalībvalstīs (koeficienti)

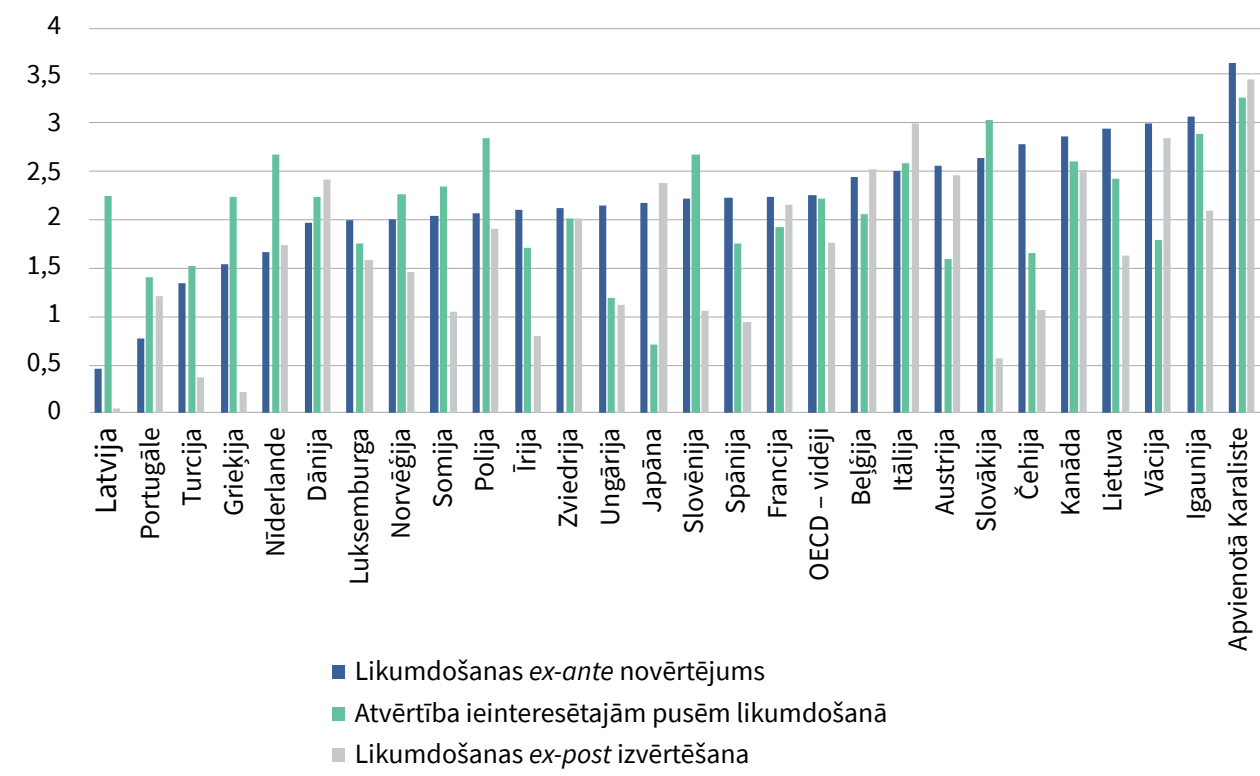

Piezīme. Novērtējums skalā no 0 līdz 4, kur 0 - zemākais - un 4 - augstākais vērtējums.

Avots: OECD Government at a Glance - 2019 edition: Regulatory governance.

Latvijā pamatprocesi, kuri nodrošina institucionālo atbildīgumu un attīstību - politisko spēku konkurence un sabiedrības/uzṇēmēju spiediens - darbojas, tomēr ar tiem nav pietiekami, par ko liecina, piemēram, pieaugošā Latvijas ekonomiskā atpalicība no kaimiņvalstīm Igaunijas un Lietuvas. Piemēram, ESAO salīdzinošā analīze ${ }^{35}$ atklāj: lēmumu pieņemšanas atvērtība Latvijā atbilst ESAO dalībvalstu caurmēra rāditājiem, taču likumdošanas iniciatīvu ex-ante un ex-post novērtējumu ziṇā Latvijas situācija ir l̦oti slikta (14. attēls). Šie trūkumi spilgti izpaudās pandēmijas laikā kontekstā ar haosu vakcīnu iegādē un valdības neizlēmību un svārstī̌sanos epidemioloğiskās situācijas vadībā.

Latvijā klaji prettiesiska rīcība valsts pārvaldes iestādēs ir kḷuvusi retums, taču institūciju sadarbības efektivitātes trūkums rada šḳēršlus saskaņotai rīcībai ne tikai ārkārtējā situācijā, bet arī mērḳtiecīgākai attīstībai normālos apstākḷos. Divas galvenās iestādes, kuras atbild par koordinācijas procesu efektivizāciju, ir Pārresoru koordinācijas centrs un Valsts kontrole.

35 OECD (2019). Government at a Glance 2019 (OECD Publishing, Paris). https://doi.org/10.1787/8 ccf5c38-en. 129, 131. 
Pārresoru koordinācijas centrs sekmē nozaru politiku savstarpējo sasaisti, stiprinot institūciju un ministriju sadarbību un vienotu rīcību kopējo valsts mērķu vārdā. Centra uzdevums ir sniegt priekšlikumus valdībai, kā īstenot valsts reformas un efektīvāk ieguldìt finanšu resursus atbilstoši valsts attīstības prioritātēm. ${ }^{36}$ Tomēr, lai arī centrs izstrādā augstākos nacionāla līmeṇa attīstības plānošanas dokumentus un rūpējas par to îstenošanu, centra viedoklim ir tikai rekomendējošs raksturs, un, kā ir konstatēts, valdība, pieņemot lēmumus par prioritārajiem pasākumiem, neizmanto centra analizi par šo pasākumu atbilstību attīstības plānošanas dokumentos noteiktajām prioritātēm un mērkiem, turklāt Ministru kabinetam izskatī̌̌anai iesniegtajiem budžeta izstrādes dokumentiem netiek pievienoti centra sagatavotie novērtējumi. ${ }^{37}$ Valsts kontrole savukārt īsteno valsts pārvalžu iestāžu finanšu, atbilstỉbas un lietderības izvērtējumu. Kā atzīst pati Valsts kontrole, vislielākais potenciāls valsts pārvaldes ātrākā sakārtošanā ir tieši lietderības revīzijām, kuru ietvaros tiek vērtēts, vai institūcijas darbība, programmas un rīcība atbilst ekonomiskuma, produktivitātes un efektivitātes principiem. ${ }^{38}$ Lai arī Valsts kontroles paveiktais ir iespaidīgs - 2019. gadā ieviesto Valsts kontroles ieteikumu īpatsvars pārsniedza 93 \% -, tās darbs ir selektīvs un reaktivs (ex-post).

\section{Secinājumi}

Lai arī Covid-19 pandēmija bija izaicinājums visām valstīm, pat vislabāk sagatavotajām, valdību reagéēšanas efektivitāte un ātrums bija ḷoti atšķirīgi. Pandēmijas pirmā viḷna laikā Latvijas valdības īstenotie ierobežojošie pasākumi bija pietiekami efektīvi, kas arī atspoguḷojās valdības darba pozitīvajā sabiedrības novērtējumā. Sabiedrība atbalstijja ierobežojumu īstenošanu, taču problēmas radīja individuālo aizsardzības līdzekḷu un citu ārstniecības resursu pārvaldības nepilnības. Pandēmijas otrais vilnis pārsteidza valdību nesagatavotu - tā nebija mācījusies no pirmā viḷna kḷūām, joprojām trūka efektīva civilās aizsardzības plāna un vienotas izpratnes par epidemiologiskās situācijas vadības principiem visā valsts pārvaldē, kā dēl infekcija strauji izplatījās, tostarp sociālās aprūpes iestādēs. Būtiskas kḷūdas tika pieḷautas arī attiecībā uz vakcīnu iepirkumu un vakcinācijas procesa sākšanu. Lai arī valsts iestādes spēja nodrošināt valsts funkciju nepārtrauktību un nepiẹ̦āva kritiskas situācijas, tomēr valdība nespēja nodemonstrēt stingra un izšḳiroša līdera lomu Covid-19 otrā viḷna krīzes vadībā.

\footnotetext{
36 “Kas ir PKC?” Pārresoru koordinācijas centra mājaslapa. https://www.pkc.gov.lv/lv/par-pkc/kas-ir-pkc.

37 Valsts kontroles atzinums "Par Latvijas Republikas 2018. gada pārskata par valsts budžeta izpildi un par pašvaldību budžetiem sagatavošanas pareizību”, 28.5. punkts.

38 Latvijas Republikas Valsts kontroles publiskais gada pārskats, 2019. 3, 13.
} 
Problēmu cēloṇi bija mantoti no pirmskrīzes perioda. Problēmu centrā ir vājais koordinācijas darbs starp valsts pārvaldes institūcijām un sektoriem, mērḳtiecības trūkums un praktiski neeksistējošais politiku efektivitātes novērtējums un mācǐšanās no konstatētajām nepilnībām. Taču starptautiskā pieredze rāda, ka attīstības plaisas pārvarēěana un pāreja uz zināšanās balstītu attīstības modeli nebūs iespējama bez starpinstitūciju darbības labākas koordinācijas un konsekventākas virzības uz definētajiem valsts attīstības mērķiem. Bez dinamiskākas un uz efektivitāti vairāk vērstas institucionālās vides publiskajā sektorā nebūs iedomājama arī noturīga ekonomiskā atjaunotne pēc pandēmijas krīzes. Šajā kontekstā Valsts prezidenta ierosinājums par jauna konstitucionālā padomdevēja orgāna Valsts padomes - izveidošanu Latvijā, kuras uzdevums būtu vērtēt likumdošanas aktu atbilstību valsts vērtībām un valsts ilgtermiṇa interesēm ${ }^{39}$, valsts ilgtspējas veicināšanas kontekstā kḷūst jēgpilns un dziḷākas izpētes vērts. Šāda autoritatīva padome kḷūtu par centrālo institūciju sabiedriskā un politiskā atbalsta mobilizēšanā attiecībā uz reformu centieniem.

39 Valsts prezidenta Egila Levita runa diskusijā "Valsts padomes loma likumdošanā”, 2020. gada 7. februāris. Pieejams: https://www.president.lv/lv/jaunumi/zinas/valsts-prezidenta-egila-levita-runa-diskusija-valstspadomes-loma-likumdosana-26124\#gsc.tab $=0$. 